\title{
PENGARUH KUALITAS PELAYANAN TERHADAP LOYALITAS KONSUMEN DENGAN KEPUASAN KONSUMEN SEBAGAI VARIABEL INTERVENING
}

\author{
Prawiniko Sugistianto ${ }^{1}$, Heri Ispriyahadi ${ }^{2 *}$ \\ ${ }^{1,2}$ STIE Muhammadiyah, Jakarta, prawinikosugistianto@gmail.com, \\ herivirpat64@gmail.com (corresponding Author)
}

\begin{abstract}
ABSTRAK
Penelitian ini bertujuan untuk mengetahui pengaruh kualitas pelayanan terhadap loyalitas konsumen pada bengkel PT Wahana Senjaya Jakarta Body \& Paint (Indomobil Nissan Datsun Warung Buncit) dengan menggunakan variabel intervening kepuasan konsumen. Sampel yang digunakan dalam penelitian sebanyak 100 pelanggan sebagai responden. Data diperoleh dengan menyebarkan kuesioner kepada responden terpilih Metode analisis dalam penelitian ini menggunakan analisis PLS (Partial Least Square). Hasil penelitian menunjukkan bahwa variabel kualitas pelayanan berpengaruh positif dan signifikan terhadap variabel loyalitas konsumen (dependen) baik secara langsung maupun tidak langsung melalui variabel kepuasan pelanggan (intervening). Demikian pula variabel kepuasan konsumen juga berpengaruh positif dan signifikan terhadap loyalitas konsumen. Kualitas pelayanan yang prima akan meningkatkan kepuasan pelanggan yang menjadi pendorong peningkatan loyalitas konsumen.
\end{abstract}

Kata Kunci : Kualitas Pelayanan, Kerpuasan Konsumen, Loyalitas Konsumen

\begin{abstract}
This study aims to investigates the effect of service quality on consumer loyalty at PT Wahana Senjaya Jakarta Body \& Paint workshop (Indomobil Nissan Datsun Warung Buncit) by using intervening variables customer satisfaction. The sample used in the study was 100 customers as respondents. Data obtained by distributing questionnaires to selected respondents. The method of analysis in this study uses PLS analysis (Partial Least Square). The results showed that the variable service quality positively and significantly affects the consumer loyalty variable (dependent), either directly or indirectly, through the variable customer satisfaction (intervening). Likewise, the variable customer satisfaction also has a positive and significant effect on customer loyalty. Excellent service quality will increase customer satisfaction which is the driving force for increased consumer loyalty.
\end{abstract}

Keywords: Service Quality, Customer Satisfaction, Customer Loyalty

Naskah diterima : 15-02-2021 Naskah dipublikasikan: 31-03-2021

\section{PENDAHULUAN}

Tujuan utama perusahaan adalah bagaimana agar mampu memberikan pelayanan terbaik bagi konsumen. Hal ini perlu dilakukan karena perusahaan akan sulit mempertahankan kelangsungan hidupnya tanpa didukung keberadaan konsumen yang loyal. Untuk mencapai tujuan tersebut, maka sudah sewajarnya perusahaan secara konsisten dan berkesinambungan menyajikan layanan yang kompetitif agar memuaskan konsumennya. Hal terbaik yang dapat dilakukan adalah memperlakukan konsumen seperti raja yaitu berupaya memenuhi harapan 
mereka atas layanan yang diberikan. Layanan yang memuaskan pelanggan harus menjadi prioritas utama sehingga perusahaan memiliki daya saing yang unggul dibandingkan pesaingnya. Perusahaan yang mampu secara tepat mengidentifikasi dan memenuhi kebutuhan konsumen akan lebih mudah memberikan kepuasan pada konsumennya.

Lovelock \& Wirtz (2011) mengatakan bahwa perusahaan akan berkembang apabila mampu mempertahankan konsumen yang loyal yang menjadi sumber gagasan untuk meningkatkan kualitas produknya. Kelangsungan hidup perusahaan akan lebih terjamin bila mampu mempertahankan loyalitas konsumen. Selain itu, perusahaan juga akan memiliki keunggulan yaitu level kompetisi yang baik sehingga mampu menghadapi para pesaingnya terutama kompetisi terkait produk dan pesepsi dari konsumen.

Konsumen yang loyal sangat bermanfaat bagi perusahaan karena akan berulang-ulang dan terus menerus melakukan pembelian produk atau layanan jasa yang diberikan perusahaan. Hal ini akan memberikan dampak jangka panjang bagi kelangsungan bisnis perusahaan. Loyalitas konsumen akan tercermin dari pembelian yang dilakukan secara berulang-ulang dan teratur oleh konsumen (Hasan 2008). Berdasarkan penjelasan tersebut, maka sangat penting untuk mempertahankan konsumen yang loyal karena apabila perusahaan mampu memuaskan kebutuhan konsomen, maka mereka akan berulang kali melakukan pembelian suatu produk atau menggunakan jasa yang diberikan oleh perusahaan.

Mepertimbangkan manfaat dari loyalitas konsumen, maka layanan yang berkualitas dan mampu memuaskan konsumennya menjadi prioritas utama bagi perusahaan. Loyalitas konsumen merupakan faktor utama yang menjadi fokus perusahaan. Perusahaan akan mampu bertahan dan mendapatkan kepercayaaan konsumen apabila menempatkan kualitas layanan yang prima sebagai target utama. Hal ini merujuk pada pandangan Goeth \&Davis (1994) yang menyebutkan layanan yang berkualitas apabila mampu memenuhi dan melebihi harapan konsumen atas produk, jasa, manusia, proses dan lingkungan dengan memperhatikan kondisi yang dinamis.

PT. Wahana Senjaya Jakarta adalah salah satu bengkel resmi Nissan Datsun yang juga menerima perbaikan body \& paint untuk mobil dengan merek Nissan dan Datsun. Indomobil Nissan Datsun Warung Buncit tidak hanya menyediakan jasa perbaikan body \& paint tetapi juga menerima jasa perbaikan general repair. Fenomena masalah yang ditemukan pada bengkel body \& paint PT Wahana Senjaya Jakarta adalah konsumen yang datang melakukan perbaikan bodi dan pengecatan di Indomobil Nissan Datsun Warung Buncit mengalami penurunan dalam rentang waktu 2018 sampai dengan 2019. Data diperoleh berdasarkan data unit entry bengkel. Pada bulan Januari hingga ke akhir Maret 2020 unit yang diperbaiki juga belum meningkat. Untuk bulan Januari sebanyak 97 unit, bulan Februari 103 unit, bulan Maret 65 unit dan pada saat melakukan observasi di lapangan secara langsung, penulis juga menemukan unit konsumen yang sudah selesai dilakukan perbaikan datang kembali ke bengkel beberapa hari kemudian untuk melakukan komplain mengenai hasil perbaikannya. Data akhir tahun 2019 turun sekitar 10\% dari data 2018 seperti yang dapat kita lihat pada tabel unit perbaikan bengkel Indomobil Nissan Datsun Warung Buncit. 


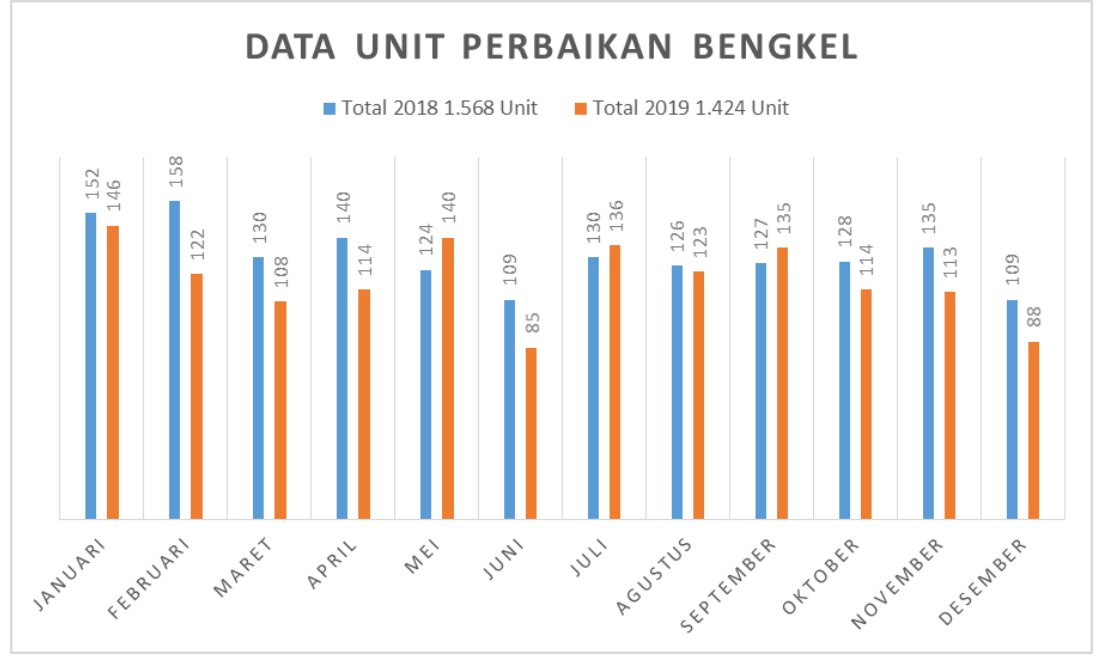

Gambar 1. Data Unit Perbaikan 2018-2019

Sumber: Data manajemen bengkel PT Wahana Senjaya Jakarta (2020)

Penelitian yang dilakukan tidak lepas dari beberapa penelitian terdahulu yang dapat dijadikan rujukan dan ada keterkaitannya dengan penelitian ini. Hasil penelitian sebelumnya Sukerti (2020) dan Dewi (2020) yang juga menggunakan kepuasan konsumen sebagai variabel intervening, menemukan layanan yang berkualitas memberikan pengaruh positif pada loyalitas pelanggan. Hasil berbeda dketemukan penelitian yang dilakukan oleh Irnandha (2016) dan Zahara (2020) ternyata kualitas layanan tidak berpengaruh pada loyalitas konsumen saat menggunakan variabel intervening kepuasan konsumen. Namun kualitas layanan berpengaruh langsung kepada loyalitas konsumen.

Penelitian ini mereplikasi penelitian-penelitian sebelumnya dengan menambahkan variabel intervening kepuasan konsumen untuk meneliti pengaruh kualitas pelayanan terhadap loyalitas konsumen pada Bengkel Body \& Paint PT. Wahana Senjaya Jakarta. Dengan menggunakan kepuasan konsumen sebagai variabel intervening, hasil penelitian ini diharapkan dapat mengetahui pengaruh kualitas layanan terhadap loyalitas konsumen.

\section{KAJIAN LITERATUR Kualitas Layanan}

Jasa dikatakan berkualitas apabila dengan segala atributnya memiliki kemampuan untuk secara riil mampu memenuhi harapan konsumen (Alma 2004). Faktor utama yang dijadikan ukuran untuk menilai kualitas jasa terdiri dari expected service dan perceived sevice. Harapan konsumen diwujudkan berdasarkan kualitas jasa yang baik dan memuaskan dari jasa yang diterima (expected service) atau jasa yang dirasakan (perceived service).

Kriteria menjadi hal yang perlu untuk sebagai dasar apakah kualitas layanan dikatakan baik atau buruk. Organisasi dapat meningkatkan kualitas pelayanan dengan menggunakan metode yang diturunkan secara empiris yaitu SERVQUAL. Untuk mengukur kualitas pelayanan menggunakan 5 (lima) dimensi terdiri dari Tangible (Berwujud), Reliability (Kehandalan), Responsiveness (Ketanggapan), Assurance (Jaminan), dan Emphaty (Empati) sesuai pendapat (Zeithaml 1990).

\section{Kepuasan Konsumen}

Konsumen dikatakan puas atau tidak puas berdasarkan hasil evaluasi purna beli apakah pembeliannya sekurang-kurangnya sama atau melampaui harapan konsumen (Tjiptono 2014). 
Dengan demikian dapat dikatakan bahwa konsumen memiliki persepsi atas suatu produk atau jasa apakah sesuai atau tidak harapannya menjadi tolak ukur kepuasan. Kalau sesuai dengan ekspekatasinya maka konsumen merasa puas, namun apabila tidak sesuai harapan maka konsumen menjadi tidak puas.

\section{Loyalitas Konsumen}

Menurut Rahmayanty (2010) Loyalitas adalah pembelian berulang yang dilakukan konsumen dalam jangka waktu tertentu sejak pembelian pertama. Aset penting bagi perusahaan adalah memiliki konsumen yang loyal. Griffin dalam Hurriyati (2010) menyatakan karakteris konsumen yang loyal adalah :

1. Melakukan pembelian secara teratur dan berulang

2. Membeli lini produk dan jasa

3. Mereferensikan kepada orang lain

4. Menunjukan daya tahan atau kekebalan terhadap tarikan pesaing

\section{Kerangka Pemikiran}

Kepuasan konsumen atas produk dan jasa dapat dipengaruhi oleh kualitas pelayanan. Konsumen merasa puas apabila mendapatkan kualitas pelayanan yang baik atas barang dan jasa. Kerangka pemikiran pengaruh kualitas pelayanan terhadap loyalitas konsumen dengan variabel intervening kepuasan konsumen secara sistematis dapat digambarkan sebagai berikut:

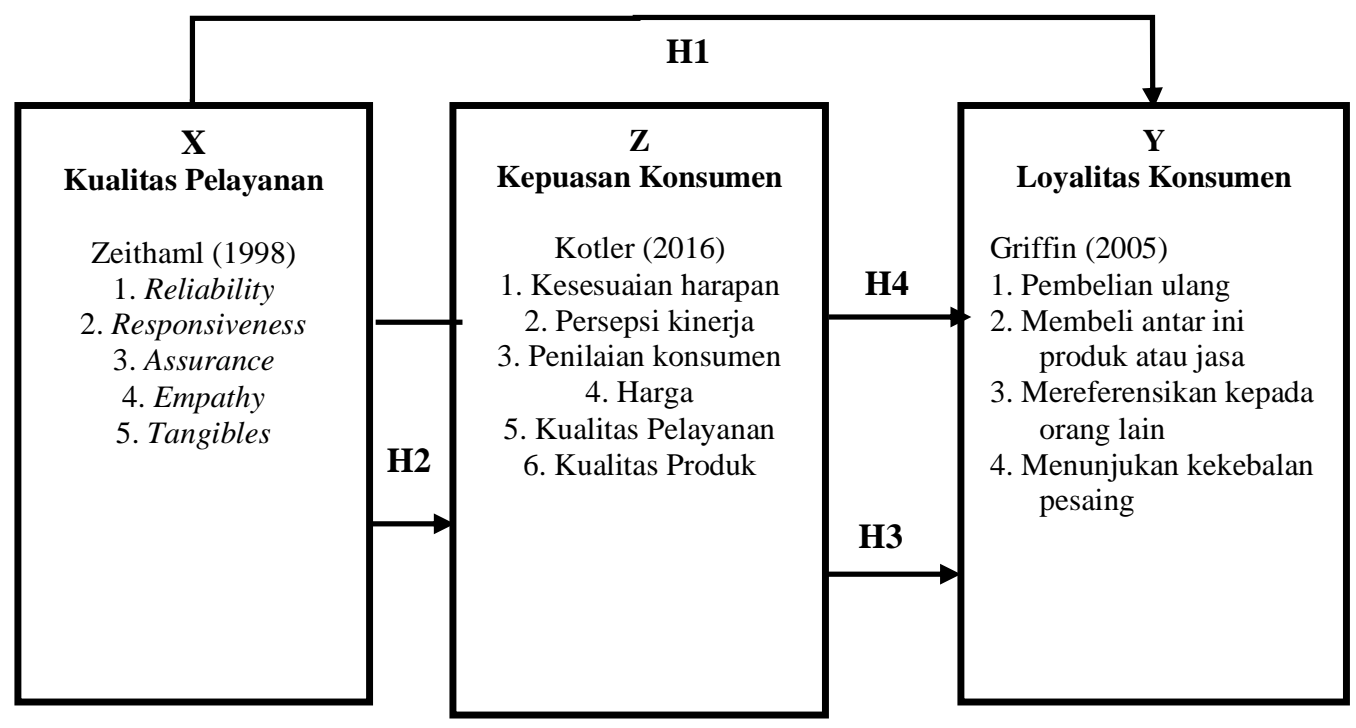

Gambar 2. Kerangka Pemikiran

Sumber: Zeithaml (1998), Kotler (2016), Griffin (2005)

\section{Pengembangan Hipotesis}

Permasalah dalam penelitian ini adalah masalah asosiatif (kausal) yaitu menganalisis keterkaitan atau hubungan dua variabel atau lebih. Perumusan hipotesi dalam penelitian ini sebagai berikut : 


\section{Hipotesis 1: Terdapat pengaruh kualitas pelayanan terhadap loyalitas konsumen}

Setiap perusahaan harus memperhatikan atas kualitas pelayanan yang diberikan karena kualitas yang baik menjadi harapan bagi konsumen maupun perusahaan. Konsumen akan menilai baik atau buruknya kualitas pelayanan dari layanan yang diberikan perusahaan bahkan dari pertama kali konsumen menggunakan jasa pelayanan. Sedangkan pengertian loyalitas adalah orang yang secara berulang melakukan pembelian sejak pembelian pertama dalam periode rentang waktu tertentu (Rahmayanty 2010).

Kualitas telah menjadi harapan dan impian bagi semua orang baik konsumen maupun perusahaan, maka dalam hal ini kualitas jasa sangat perlu diperhatikan oleh setiap perusahaan. Kualitas pelayanan bisa dikatakan berkualitas ataupun tidak berkualitas sebenarnya didasarkan pada penilaian dari pelayanan yang diberikan, bahkan dari pertama kali konsumen menggunakan jasa pelayanan. Menurut Rahmayanty (2010) Loyalitas adalah tentang persentase dari orang yang pernah membeli dalam kerangka waktu tertentu dan melakukan pembelian ulang sejak pembelian yang pertama. Penelitian Irmanda (2016) dan Zahara (2020) menemukan bahwa loyalitas pelanggan dipengaruhi secara positif dan signifikan oleh variabel kualitas layanan. Atas dasar hal-hal tersebut, perumusan hipotesis adalah:

$\left(\mathrm{H}_{1}\right)$ Kualitas pelayanan berpengaruh positif terhadap loyalitas konsumen.

\section{Hipotesa 2 : Pengaruh kualitas pelayanan terhadap kepuasan konsumen}

Untuk memuaskan konsumen maka bergantung pada baik buruknya kualitas pelayanan yang diberikan oleh penyedia jasa. Hal ini terkait erat dengan pandangan konsumen atas layanan tersebut sehingga sulit untuk didefiniskan. Terkait dengan hal tersebut, maka perusahaan perlu untuk secara konsisten meningkatkan kualitas layanan agar dapat memuaskan konsumen. Kepuasan konsumen bisa diwujudkan dengan memliki layanan yang berkualitas yaitu memiliki keunggulan atas harapan dan pengendalian sehingga konsumen puas (Parasuraman, et al. 1998). Konsumen memiliki persepsi baik dan memuaskan atas kualitas layanan jasa yang mereka terima apabila sesuai atau melebih harapan. Hasil penelitian Rohman (2017) menemukan bahwa kualitas pelayanan berpengaruh pada kepuasan konsumen pada Bengkel Mr. Montir Citayam. Rumusan hipotesis sebagai berikut:

$\left(\mathrm{H}_{2}\right)$ Kualitas pelayanan berpengaruh positif terhadap kepuasan konsumen.

\section{Hipotesis 3 : Pengaruh kepuasan konsumen terhadap loyalitas konsumen}

Menurut Tjiptono (2014), menyatakan bahwa setelah melakukan evaluasi purnabeli, konsumen merasa puas atau tidak atas suatu produk atau jasa yang diterima. Konsumen merasa puas kalau sama atau melebih harapan konsumen. Sebaliknya konsumen merasa tidak puas apabila layanan yang diberikan tidak sesuai harapan. Konsumen yang sangat puas akan menjadi setia dan loyal sehingga berpotensi untuk memperkenalkan produk perusahaan kepada orang lain. Konsumen yang loyal tidak mudah untuk berpindah kepada produk atau layanan lain karena mereka telah memiliki komitmen atas suatu produk, bahkan akan berulangkali membeli produk atau jasa yang disukainya (Kotler dan Keller 2016). Penelitian yang dilakukan oleh Rachmawati (2014) menghasilkan temuan kepuasan konsumen akan meningkatkan loyalitas pelanggan. Atas dasar hal-hal tersebut, pada penelitian ini adalah:

$\left(\mathrm{H}_{3}\right)$ Kepuasan konsumen berpengaruh positif terhadap loyalitas konsumen. 


\section{Hipotesis 4 : Pengaruh kualitas pelayanan terhadap loyalitas konsumen dengan kepuasan konsumen sebagai variabel intervening}

Konsumen yang konsisten secara teratur dan berulang-ulang membeli suatu barang dan jasa dari suatu perusahaan adalah sikap atau perilaku loyalitas konsumen. Selain itu, konsumen tersebut juga memiliki komitmen dan sikap yang positif atas perusahaan yang menawarkan produk/ jasa tersebut. Menurut Sukerta (2020) dan Dewi (2020) dari penelitian yang mereka lakukan mendapatkan hasil pengujian bahwa kualitas pelayanan mempunyai pengaruh positif terhadap loyalitas pelanggan yang dimediasi kepuasan pelanggan. Atas dasar uraian tersebut, maka hipotesis dapat disusun sebagai berikut:

$\left(\mathrm{H}_{4}\right)$ Kualitas pelayanan berpengaruh positif terhadap loyalitas konsumen dengan kepuasan konsumen sebagai variabel intervening.

\section{METODE PENELITIAN}

\section{Desain Penelitian}

Pendekatan kuantitatif digunakan dalam penelitian ini. Data primer diperoleh dari survey yaitu dengan menggunakan kuestioner sebagai alat untuk mengumpulkan data (Cooper dan Schindler 2006). Penelitian merupakan confirmatory research karena akan menguji suatu teori atau hipotesis dengan menggunakan prosedur yang tepat dan sumber data yang spesifik. Haslnya dapat mendukung atau menolak suatu teori atau hipotesis dari penelitian-penelitian sebelumnya. Mengingat penelitian ini adalah dilakukan hanya sekali pada suatu waktu, maka tergolong crosss sectional study (Cooper dan Schindler, 2006).

\section{Populasi dan sampel}

Populasi dalam penelitian ini adalah pelanggan yang pernah memperbaiki dan mengecat mobil di bengkel body \& paint Indomobil Nissan Datsun Warung Buncit. Purposive sampling merupakan teknik sampling yang digunakan dalam penelitian ini dengan kriteria sebagai berikut:

1. Konsumen bengkel body \& paint Indomobil Nissan Datsun Warung Buncit yang melakukan perbaikan kendaraan dalam rentang waktu penelitian yaitu dimulai dari 1 Februari 2020 hingga 31 Juli 2020.

2. Konsumen telah menggunakan jasa bengkel body \& paint Indomobil Nissan Datsun Warung Buncit lebih dari satu kali.

Pemilihan jumlah sampel merujuk Ferdinand (2014) yaitu jumlah sampel adalah jumlah indikator dikalikan 5 sampai 10 kali. Dengan jumlah indikator sebanyak 15 maka besarnya sampel yang akan digunakan sebesar 75 sampai 150 responden. Berhubung dalam studi ini menggunakan SEM PLS maka sesuai Gozali (2006) jumlah sampel yang digunakan berkisar antara 30 sampai dengan 100 sampel dan Ferdinand (2005) menyatakan dalam penelitian SEM (Structural Equation Modeling) adalah minimal 100 sampel. Mempertimbangkan hal tersebut maka dalam penelitian ini jumlah sampel yang digunakan sebanyak 100 responden. Jumlah ini sesuai dengan batas minimum yang diperkenankan untuk penelitian menggunakan analisis SEM-PLS.

\section{Teknik Analisis}

\section{Partial Least Square.}

Penelitian ini menggunakan partial least square (PLS) sebagai alat analisis yang menggunakan perhitungan optimal least square fit pada korelasi atau matrik. Sebagai salah satu bentuk analisis SEM (Structural Equation Model), PLS melakukan pengujian hubungan antara 
variabel dependen (endogen) dengan beberapa variabel independen (eksogen). Faktor atau konstruk yang berupa indikator-indikator dalam varaibel-variabel tersebut akan diobservasi atau diukur langsung.

\section{Analisis Deskriptif}

Dalam analisis diskriptif, obyek yang diteliti akan digambarkan atau dideskripsikan apa adanya tanpa melakukan analisis dan membuat kesimpulan umum berdasarkan data yang telah dikumpulkan (Sugiyono 2010).

\section{Statistik Inferensial}

Software smartPLS digunakan untuk mengalisis data statistik inferensial untuk menguji hipotesis yang telah dirumuskan. Ada 3 model pengujian yaitu pengukuran model (outer model), evaluasi struktur model (inner model), pengujian hipotesis dan model analisis persamaan structural.

\section{- Pengukuran Model (Outer Model)}

Model pengukuran yang digunakan untuk menggambarkan hubungan antar blok indikator dengan variabel latennya adalah outer model (Abdillah dan Jogiyanto (2015). Dalam model ini menghubungkan antar variabel laten dengan indikator-indikatornya. Dengan kata lain, outer model mendefinisikan bagaimana setiap indikator berhubungan dengan variabel lainnya. Uji dalam Outer model sebagai berikut :

1. Convergent Validity, dinilai berdasarkan loading factor (korelasi antara skor item atau skor komponen dengan skor konstruk). Menurut Ghozali ( 2008) jika memiliki nilai $A V E$ (Average Variance Extranced) diatas 0,5 atau memperlihatkan seluruh outer loading dimensi variabel memiliki nilai loading > 0,5 maka indikator diangga valid sehingga memenuhi kriteria validitas konvergen. Sementara itu, Jogiyanto (2009) menjelaskan bahwa nilai AVE merupakan rata-rata presentase skor varian yang diekstraksi dari seperangkat variabel laten yang diestimasi melalui loading Standarized indikatornya dalam proses iterasi alogaritma dalam PLS

2. Menurut Abdillah \& Jogiyanto (2009) model dianggap mempunyai discriminant validity yang cukup jika nilai cross loading antara konstruk lebih besar dari nilai cross loading antara konstruk dengan konstruk lainnya dalam model.

3. Nilai Cronbach's Alpha dan Composite Reliability digunakan untuk uji reabilitas (Abdillah \& Jogiyanto (2009). Cronbach's Alpha untuk mengukur batas bawah nilai reliabilitas suatu konstruk sedangkan Composite Reliability mengukur nilai sesungguhnya reliabilitas suatu konstruk. Namun Composite Reliability dinilai lebih baik dalam mengestimasi konsistensi internal suatu konstruk. Suatu konstruk atau variabel dikatakan reliabel jika memberikan nilai Cronbach's Alpha > 0,7 dan Composite Reliability > 0,7.

\section{- Evaluasi Struktur Model (Inner Model)}

Untuk memprediksi adanya hubungan kausalitas antar varaibel laten menggunakan model struktural atau inner model yaitu menggunakan Coefficient of Determination $\left(\mathrm{R}^{2}\right)$ dan Path Coefficient $(\beta)$ sebagai dasar untuk melihat dan meyakin hubungan antar konstruk ((Abdillah dan Jogiyanto 2009).

\section{Uji Hipotesis}

Cara untuk mengukur signifikansi dari suatu hipottesis dilakukan dengan membandingkan nilai T-table dan T-Statistic. Hipotesis akan diterima kalau T-Statistic lebih 
tinggi dibandingkan dengan T-Table. T-Table untuk hipotesis yang dilakukan dalam penelitian ini sebesar > 1.66008 karena menggunakan tingkat keyakinan 95\% (alpha 95 persen).

\section{HASIL DAN PEMBAHASAN}

Karakteristik Responden

Karakteristik responden merupakan keragaman latar belakang yang para responden miliki. Karakteristik ini untuk melihat bagaimana background dari reponden. Latar belakang responden difokuskan pada jenis kelamin, usia, pendidikan, pekerjaan, pendapatan dan tingkat frekuensi. Hasil yang didapat pada responden dalm penelitian ini adalah:

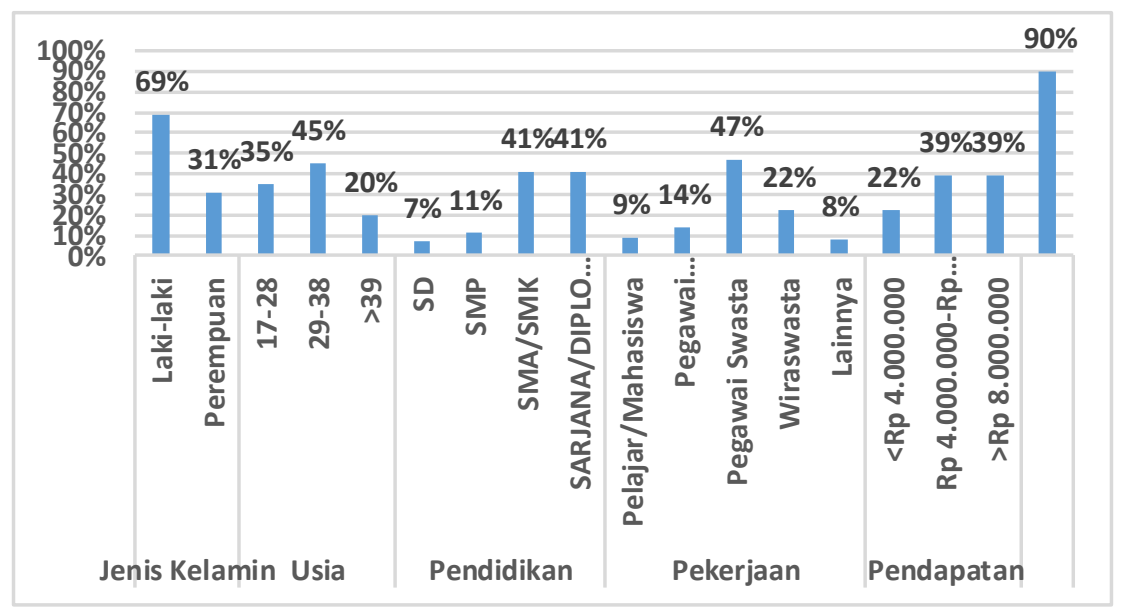

Gambar 3. Grafik Karakteristik Responden Sumber: Data diolah (2020)

Grafik Karakteristik responden di atas menunjukkan bahwa rsponden mayoritas berjenis kelamin laki-laki dengan frekuensi 69 responden dari total 100 responden yang berpartisipasi. Untuk jenis kelamin perempuan yang berpartisipasi sebanyak 31 responden. Usia responden pada penelitian ini didominasi oleh responden pada usia 29 hingga 38 tahun sebanyak 45 responden. Untuk usia 39 tahun ke atas sebanyak 20 responden dan 35 responden berada pada usia 17 hingga 28 tahun. Karakteristik responden ditinjau dari pendidikan menunjukkan jumlah responden yang sama banyaknya untuk pendidikan SMA/SMK dan SARJANA/DIPLOMA sebanyak masing-masing 41 responden. Untuk pendidikan SMP responden yang berpartisipasi sebanyak 11 responden dan sisa 7 responden adalah responden dengan pendidikan SD. Mayoritas responden yang berpartisipasi jika kita melihat dari stastus pekerjaan adalah Pegawai Swasta dengan 47 responden. Untuk terbanyak kedua adalah Wiraswasta dengan 22 responden. Untuk responden dengan status pekerjaan Pegawai Negeri/TNI-POLRI dan Pelajar/Mahasiswa masing-masing 14 dan 9 responden. Responden yang terkecil adalah responden dengan status pekerjaan lainnya sebanyak 8 responden. Jumlah responden terendah ditinjau dari pendapatan adalah responden dengan pendapatan tiap bulan dibawah $\mathrm{Rp} 4.000 .000$, sedangkan pendapatan Rp 4.000.000-Rp 8.000.000 dan pendapatan lebih dari Rp 8.000.000 jumlahnya sama yaitu sebanyak 39 responden masing-masing.

\section{Statistik Deskriptif}

Analisis statistik deskriptif dilakukan untuk memperoleh nilai minimal, nilai maksimal, nilai mean (Me), dan Standar Deviasi (SD). Dari tiga variabel yang diteliti, data ststistik deskriptif yang dihasilkan adalah sebagai berikut: 
Tabel 1. Statistik Deskriptif

\begin{tabular}{|c|c|c|c|c|c|c|c|}
\hline & $\mathrm{N}$ & Range & $\begin{array}{c}\text { Minimu } \\
\mathrm{m}\end{array}$ & $\begin{array}{c}\text { Maximu } \\
\mathrm{m}\end{array}$ & \multicolumn{2}{|c|}{ Mean } & \multirow{2}{*}{$\begin{array}{c}\begin{array}{c}\text { Std. } \\
\text { Deviation }\end{array} \\
\text { Statistic }\end{array}$} \\
\hline & Statistic & Statistic & Statistic & Statistic & $\begin{array}{c}\text { Statisti } \\
\text { c }\end{array}$ & Std. Error & \\
\hline $\begin{array}{c}\text { Variabel_ } \\
\mathrm{X}\end{array}$ & 100 & 23.00 & 27.00 & 50.00 & 37.08 & .502 & 5.023 \\
\hline $\begin{array}{c}\text { Variabel_ } \\
\mathrm{Z}\end{array}$ & 100 & 27.00 & 33.00 & 60.00 & 44.48 & .603 & 6.029 \\
\hline $\begin{array}{c}\text { Variabel_ } \\
\text { Y }\end{array}$ & 100 & 18.00 & 21.00 & 39.00 & 30.10 & .388 & 3.881 \\
\hline $\begin{array}{l}\text { Valid N } \\
\text { (listwise) }\end{array}$ & 100 & & & & & & \\
\hline
\end{tabular}

Sumber: Data diolah (2020)

Hasil dari pengolahan data statistik deskriptif variabel Kualitas Pelayanan (X) memiliki nilai mean sebesar 37,08 dengan standar eror di 0,502 dan range 23 dengan nilai minimum 27 dan maksimum 50 untuk standar deviasinya sebesar 5,023. Hasil dari pengolahan data statistik deskriptif variabel Kepuasan Konsumen (Z) memiliki nilai mean sebesar 44,48 dengan standar eror di 0,603 dan range 27 dengan nilai minimum 33 dan maksimum 60 untuk standar deviasinya sebesar 6,029. Hasil dari pengolahan data statistik deskriptif variabel Loyalitas Konsumen (Y) memiliki nilai mean sebesar 30,10 dengan standar eror di 0,388 dan range 18 dengan nilai minimum 21 dan maksimum 39 untuk standar deviasinya sebesar 3,881.

\section{Menilai Outer Model atau Measurement Model}

Untuk menilai outer model dalam teknik analisis data dengan SmartPLS menggunakan tiga kriteria yaitu Convergent Validity, Discriminant Validity dan Composite Reliability. Convergent validity dari model pengukuran dengan refleksif indikator dinilai berdasarkan korelasi antara item score/component score yang diestimasi dengan Software SmartPLS. jika berkorelasi lebih dari 0,70 dengan konstruk yang diukur, maka ukuran refleksif individual dikatakan tinggi. Pada penelitian tahap awal menurut Chin (1998) skala pengukuran nilai loading 0,5 sampai 0,6 dianggap cukup memadai. Berdasarkan hal tersebut, maka penelitian ini akan digunakan batas loading factor sebesar 0,50.

Hasil uji validitas dilakukan dengan beberapa tahapan terhadap 100 kuesioner yaitu dengan melakukan eliminasi terhadapi indikator-indikator yang tidak valid, maka diperoleh hasil sebagai berikut: 
Gambar 4. Uji Validitas Tahap Akhir

Sumber: Hasil Algorithm SmartPls (2020)

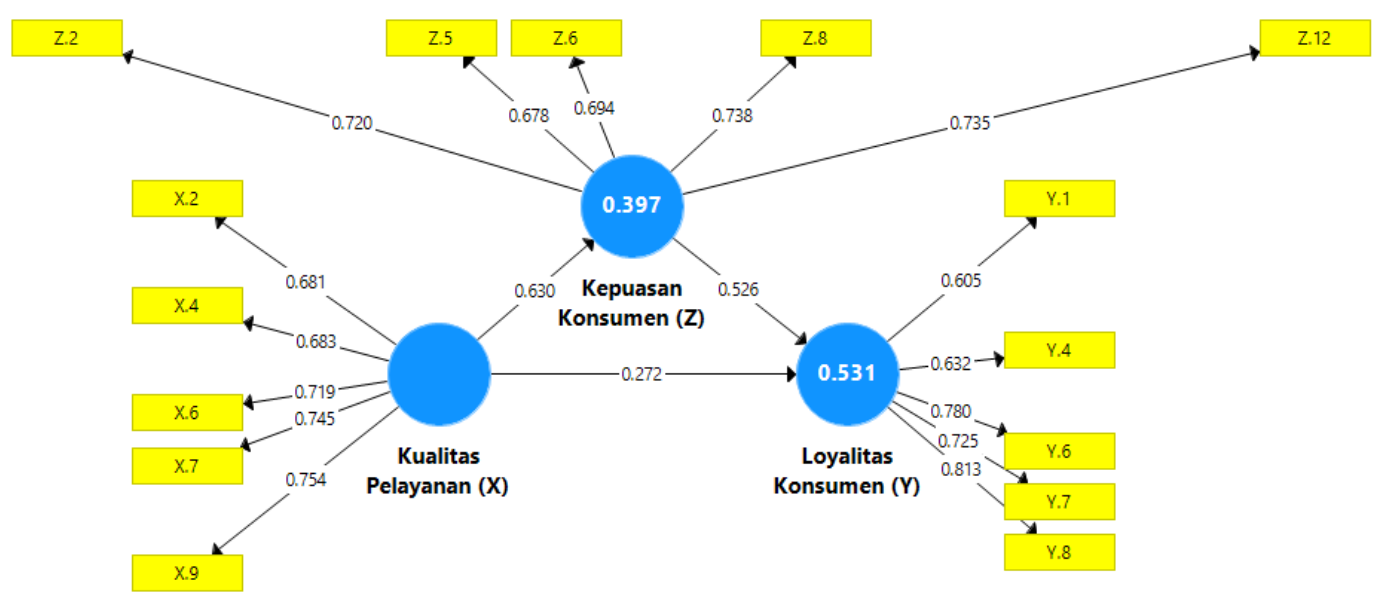

Gambar 4. Uji Validitas Tahap Akhir

Sumber: Hasil Algorithm SmartPls (2020)

Tabel berikut ini menggambarkan Hasil Uji Reliabilitas :

Tabel 2. Uji Reliabilitas

\begin{tabular}{|l|r|r|r|}
\hline \multicolumn{1}{|c|}{ Variabel } & $\begin{array}{c}\text { Cronbach's } \\
\text { Alpha }\end{array}$ & $\begin{array}{r}\text { Composite } \\
\text { Reliability }\end{array}$ & AVE \\
\hline $\begin{array}{l}\text { Kepuasan Konsumen } \\
\text { (Z) }\end{array}$ & 0,760 & 0,838 & 0,509 \\
\hline Kualitas Pelayanan (X) & 0,764 & 0,841 & 0,514 \\
\hline $\begin{array}{l}\text { Loyalitas Konsumen } \\
\text { (Y) }\end{array}$ & 0,757 & 0,838 & 0,512 \\
\hline
\end{tabular}

Sumber: Data diolah (2020)

Dari hasil uji reabilitas pada tabel 2 menunjukkan bahwa variabel kualitas pelayanan, kepuasan konsumen dan loyalitas konsumen memiliki angka composite reliability diatas 0,8 dan memiliki angka cronbach's alpha sebesar 0,7. Dengan demikian dapat disimpulkan bahwa indikator tersisa pada masing-masing variabel mempunyai reliabilitas yang baik serta mampu untuk mengukur konstruknya.

\section{Pengujian Inner Model atau Structural Model}

Untuk mendapatkan hubungan konstruk, , nilai signifikansi dan $R$-square dari model penelitian dapat dilakukan dengan pengujian inner model atau model struktural. Dalam melakukan evaluasi model struktural digunakan R-square untuk konstruk dependen uji t serta signifikansi dari koefisien parameter jalur struktural. Dalam PLS, model structural menggunakan $\mathrm{R}^{2}$ untuk mengevaluasi variabel dependen dan untuk variabel independen 
memakai nilai koefisien path. Sedangkan nilai signifikansinya dilihat berdasarkan nilai tstatistic setiap path.

Tabel 3. Nilai R Square

\begin{tabular}{|l|r|r|}
\hline \multicolumn{1}{|c|}{ Variabel } & R Square & $\begin{array}{l}\text { R Square } \\
\text { Adjusted }\end{array}$ \\
\hline $\begin{array}{l}\text { Kepuasan Konsumen } \\
\text { (Z) }\end{array}$ & 0,397 & 0,391 \\
\hline $\begin{array}{l}\text { Loyalitas Konsumen } \\
\text { (Y) }\end{array}$ & 0,531 & 0,522 \\
\hline
\end{tabular}

Sumber: Data diolah (2020)

Dari tabel 3 di atas, nilai $R$ Square $\left(\mathrm{R}^{2}\right)$ variabel kepuasan konsumen sebesar 0,397 yang mengindikasikan bahwa 39,7 \% kualitas pelayanan dapat menjelaskan keragaman kepuasan konsumen. Sisanya sebesar $60,3 \%$ dipengaruhi oleh variabel lain yang tidak ada dalam penelitian. Variabel Loyalitas konsumen sebesar 0,531 mengindikasikan bahwa keragaman loyalitas konsumen dapat dijelaskan oleh variabel kualitas pelayanan dan kepuasan konsumen sebesar $53,1 \%$ dan sisanya sebesar $46,9 \%$ dipengaruhi oleh variabel lain yang tidak ada pada model penelitian.

\section{Goodness of fit}

Nilai Q-Square merupakan dasar untuk menilai goodness of fit. Model semakin baik atau fit dengan data apabila semakin tinggi Q-Square atau sama dengan coefficient determination ( $R$-Square) pada analisis regresi. Hasil perhitungan nilai $Q$-Square adalah sebagai berikut:

$$
\begin{aligned}
\text { Q-Square } & =1-\left[\left(1-\mathrm{R}^{2} 1\right) \times\left(1-\mathrm{R}^{2} 2\right)\right] \\
& =1-[(1-0,397) \times(1-0,531)] \\
& =1-(0,603 \times 0,469) \\
& =1-0,282 \\
& =0,718
\end{aligned}
$$

Nilai sebesar 0,718 atau $71,8 \%$ merupakan nilai predictive relevance dari model structural dalam penelitian ini. Penggunaan kepuasan konsumen sebagai variabel intervening dalam model prediksi mampu menjelaskan pengaruh kualitas layanan terhadap loyalitas konsumen sebesar $71,8 \%$. Dengan demikian model memiliki prediktif yang baik sehingga dapat digunakan untuk pengujian hipotesis.

\section{Uji Hipotesis}

Nilai t-statistic antara variabel independen ke variabel dependen dalam tabel Path Coefficient pada output SmartPLS menjadi dasar nilai signifikansi model prediksi dalam pengujian model structural sebagaimana dijelaskan pada table berikut ini: 
Tabel 4. Path Coefficient

\begin{tabular}{|l|r|r|r|r|c|}
\hline \multicolumn{1}{|c|}{$\begin{array}{c}\text { Hubungan antar } \\
\text { variabel }\end{array}$} & $\begin{array}{c}\text { Origina } \\
\text { I } \\
\text { Sample } \\
(\mathbf{O})\end{array}$ & $\begin{array}{c}\text { Sample } \\
\text { Mean } \\
\text { (M) }\end{array}$ & $\begin{array}{c}\text { Standard } \\
\text { Deviation } \\
\text { (STDEV) }\end{array}$ & $\begin{array}{c}\text { T Statistics } \\
(\mid \mathbf{O} \text { (STDEV } \\
\text { ) }\end{array}$ & $\begin{array}{c}\text { P } \\
\text { Value } \\
\text { S }\end{array}$ \\
\hline $\begin{array}{l}\text { Kualitas Pelayanan } \\
\text { (X) -> Loyalitas } \\
\text { Konsumen (Y) }\end{array}$ & 0.272 & 0.258 & 0.094 & 2.907 & 0.002 \\
\hline $\begin{array}{l}\text { Kualitas Pelayanan } \\
\text { (X) -> Kepuasan } \\
\text { Konsumen (Z) }\end{array}$ & 0.630 & 0.637 & 0.074 & 8.464 & 0.000 \\
\hline $\begin{array}{l}\text { Kepuasan Konsumen } \\
\text { (Z) -> Loyalitas } \\
\text { Konsumen (Y) }\end{array}$ & 0.526 & 0.543 & 0.079 & 6.616 & 0.000 \\
\hline $\begin{array}{l}\text { Kualitas Pelayanan } \\
\text { (X) -> Loyalitas } \\
\text { Konsumen (Y) } \\
\text { melalui kepuasan } \\
\text { konsumen }\end{array}$ & 0.331 & 0.346 & 0.068 & 4.869 & 0.000 \\
\hline
\end{tabular}

Sumber: Data diolah (2020)

\section{Pengujian Hipotesis $\mathbf{H}_{1}$}

Dari tabel 4 dapat dilihat nilai original sample estimate adalah sebesar 0,272 dengan signifikansi dibawah 5\% yang ditunjukkan dengan nilai tstatistik 2,907 lebih besar dari nilai t-statistik sebesar 1,66. Nilai original sample estimate positif mengindikasikan bahwa kualitas pelayanan berpengaruh positif dan signifikan terhadap loyalitas konsumen atau $\mathrm{H}_{1}$ diterima.

\section{Pengujian Hipotesis $\mathbf{H}_{2}$}

Pengujian kedua dilakukan untuk melihat apakah kualitas pelayanan berpengaruh positif terhadap kepuasan kosumen. Hasil pengujian dapat dilihat dari tabel 4., kualitas pelayanan memperoleh nilai original sample estimate sebesar 0,630 dengan nilai tstatistik 8,464>1,66 yang berarti kualitas pelayanan berpengaruh positif dan signifikan terhadap kepuasan konsumen dengan tingkat signifikansi dibawah 5\%. Dengan demikian $\mathrm{H}_{2}$ diterima.

\section{Pengujian Hipotesis $\mathrm{H}_{3}$}

Pengujian hipotesis ketiga ditujukan untuk melihat pengaruh kepuasan konsumen terhadap loyalitas konsumen. Berdasarkan hasil pengujian, kepuasan konsumen memperoleh nilai original sample estimate sebesar 0,526 dengan nilai t-statistik 6,616 > 1,66. Dari hasil regresi hipotesis tersebut dapat simpulkan bahwa $\mathrm{H}_{3}$ diterima yaitu kepuasan konsumen berpengaruh positif dan signifikan terhadap loyalitas konsumen tingkat signifikansi dibawah $5 \%$.

\section{Pengujian Hipotesis $\mathbf{H}_{4}$}

Pengujian keempat dilakukan untuk melihat apakah kualitas pelayanan berpengaruh positif terhadap kepuasan kosumen dengan menggunakan variabel kepuasan konsumen sebagai variabel intervening. Hasil pengujian dapat dilihat dari tabel di atas, kualitas pelayanan memperoleh nilai original sample estimate sebesar 0.331 dengan nilai tstatistik $4.869>1,66$ yang berarti kualitas pelayanan berpengaruh positif dan signifikan 
terhadap loyalitas konsumen dengan kepuasan konsumen sebagai variabel intervening. Berdasarkan hasil pengujian tersebut dapat disimpulkan bahwa $\mathrm{H}_{4}$ diterima.

\section{PEMBAHASAN}

\section{Pengaruh kualitas pelayanan terhadap loyalitas konsumen}

Hasil pengujian hipotesis menunjukkan bahwa kualitas pelayanan berpengaruh positif dan signifikan pada loyalitas konsumen. Kualitas layanan dengan capaian yang paling tinggi pada indikator Assurance, empathy, dan tangibles. Hal ini dapat menjelaskan bahwa loyalitas dari konsumen dapat terbentuk dari kualitas pelayanan yang selalu konsisten dengan standar pelayanan yang baik. Perusahaan yang mampu secara konsisten dan berkesinambungan meningkatkan kualitas pelayanan kepada pelanggannya akan memperoleh persepsi positif pelanggannya sehingga mendorong pelanggan tersebut untuk melakukan pembelian ulang atau memakai jasa ulang atas produk yang ditawarkan perusahaan. Penelitian Irnandha (2016) juga menunjukkan bahwa kualitas pelayanan memiliki pengaruh positif terhadap loyalitas konsumen.

\section{Pengaruh kualitas pelayanan terhadap kepuasan konsumen}

Berdasarkan pengujian memperoleh hasil bahwa kualitas pelayanan berpengaruh positif dan signifikan pada kepuasan kosumen. Hal ini menunjukkan bahwa berbagai upaya meningkatkan kualitas pelayanan yang dilakukan oleh perusahaan sampai pelayanan purna jual mendapat persepsi positif dari konsumennya. Kotler dan Keller (2016) menjelaskan bahwa kepuasan adalah perasaan seseorang antara terpuaskan atau dikecewakan atas produk atau jasa yang sudah dibelinya dan akan dibandingkan dengan harapan konsumen saat membeli produk atau jasa tersebut. Dengan demikian dapat dikatakan perusahaan mampu memenuhi harapan konsumen atas pelayanan yang dibutuhkan oleh konsumen sehingga konsumen puas. Penelitian serupa yang dilakukan oleh Rohman (2017) menemukan bahwa kualitas pelayanan berpengaruh pada kepuasan konsumen.

\section{Pengaruh kepuasan konsumen terhadap loyalitas konsumen}

Hasil pengujian menunjukkan kepuasan konsumen memberikan pengaruh positif dan signifikan terhadap loyalitas konsumen. Konsumen yang puas akan meningkatkan kepercayaan dan kesetiaan atas layanan produk dan jasa yang diberikan oleh perusahaan atau meningkatkan loyalitas konsumen. Hal ini mengacu pada pendapat yang disampaikan oleh Kotler dan Keller (2016) yang menyatakan loyalitas adalah komitmen yang mendalam dari konsumen untuk melakukan pembelian kembali atas produk barang atau jasa pada masa mendatang. Oleh karena itu, perusahaan harus menfokuskan bagaimana memberikan kepuasan konsumen karena akan berdampak meningkatkan loyalitas konsumen. Penelitian yang dilakukan oleh Rachmawati (2014) juga menemukan bahwa kepuasan konsumen akan meningkatkan loyalitas pelanggan sehingga memperkuat penelitian ini.

\section{Pengaruh kualitas pelayanan terhadap loyalitas konsumen dengan kepuasan konsumen sebagai variabel intervening}

Hasil penelitian menunjukkan bahwa dengan menggunakan kepuasan konsumen sebagai variable intervening, diperoleh hasil kualitas pelayanan memiliki pengaruh positif dan signifikan terhadap loyalitas konsumen. Dengan demikian dapat dikatakan kualitas pelayanan dapat secara langsung maupun tidak langsung mempengaruhi loyalitas konsumen. Namun yang menarik dari hasil penelitian ini adalah ternyata kualitas layanan berdampak lebih besar apabila menggunakan intervening kepuasan konsumen untuk mempengaruhi loyalitas konsumen atau hubungan tidak langsung dibandingkan dengan hubungan langsung. Oleh karena itu perusahaan 
sebaiknya lebih memprioritas kualitas layanan yang diberikan pada faktor-faktor yang memengaruhi kepuasan konsumen seperti persepsi, harga, kualitas layanan dan kualitas produk. Konsumen yang puas akan mendorong mereka untuk lebih loyal kepada produk atau jasa yang diberikan perusahaan. Peneltian sebelumnya yang dilakukan Zahara (2020) meberikan hasil yang berbeda. Zahara menemukan bahwa kualitas pelayanan hanya mempengaruhi loyalitas konsumen jika secara langsung tanpa dimediasi oleh kepuasaan konsumen.

\section{PENUTUP}

\section{Simpulan}

Tujuan penelitian ini untuk menguji pengaruh kualitas pelayanan terhadap loyalitas konsumen dengan variabel intervening kepuasan konsumen baik secara langsung maupun tidak langsung pada bengkel body \& paint Indomobil Nissan Datsun Warung Buncit (PT. Wahana Senjaya Jakarta). Hasil penelitian menunjukkan adanya pengaruh positif dan signifikan secara langsung kualitas pelayanan pada loyalitas konsumen dengan indikator Assurance, empathy, tangibles yang paling tinggi. Demikian pula saat menggunakan kepuasan konsumen sebagai variable intervening, kualitas pelayanan secara tidak langsung juga memiliki pengaruh positif pada loyalitas konsumen dengan indikator yang paling tinggi adalah mereferensikan kepada orang lain. Dari hasil penelitian ini maka perusahaan harus selalu kosisten untuk terus meningkatkan kualitas layanan sehingga meningkatkan kepuasan konsumen yang pada akhirnya dapat mendorong meningkatnya loyalitas konsumen.

Hasil penelitian ini bermanfaat bagi konsumen dan perusahaan. Konsumen akan memperoleh layanan terbaik dan perusahaan akan mampu mepertahankan dan meningkatkan loyalitas konsumen apabila dapat memberikan kualitas layanan sesuai atau melebih harapan pelanggannya. Hal ini perlu dilakukan karena terbukti berdasarkan hasil penelitian kualitas pelayanan memberikan dampak positif bagi loyalitas konsumen. Selain itu, keuntungan yang diperoleh perusahaan adalah apabila konsumen puas atas layanan perusahaan selain loyal juga akan mereferensikan kepada konsumen baru.

\section{Saran}

Disadari bahwa penelitian ini memiliki sejumlah keterbatasan. Pertama, terkait cakupan data. Data yang digunakan terbatas pada data konsumen bengkel body \& paint PT Wahana Senjaya Jakarta (Indomobil Nissan Datsun Warung Buncit) sehingga hasil penelitian tidak bisa diterapkan untuk semua layanan jasa yang diberikan seluruh bengkel-bengkel mobil lainnya, Keterbatasan kedua, penelitian ini menggunakan 1 (satu) variabel independen yaitu kualitas layanan dan 1 (satu) varaibel invervening yaitu kepuasan konsumen. Terakhir adalah keterbatasan periode pengujian yaitu konsumen yang datang ke bengkel dari periode Februari sampai dengan Juli 2020. Untuk penelitian ke depan, kami menyarankan untuk menambahkan varaibel-varaibel independen lainnya yang berpengaruh pada loyalitas konsumen seperti harga, reputasi merk, metode pembayaran dan lainnya. 


\section{REFERENSI}

Abdillah, W. \& Jogiyanto (2009). Partial Least Square (PLS) Alternatif SEM Dalam Penelitian Bisnis. Yogyakarta: Penerbit Andi

Alma, Buchari (2004). Manajemen Pemasaran dan Pemasaran Jasa. Bandung: Alfabeta.

Cooper, Donald R \&Schindler, Pamela S (2006). Bussines Research Methods $9^{\text {th }}$ edition. McGraw-Hill International Edition.

Dewi, I.D., Respati, N.N, (2020). The Influence of Service Quality on Customer Loyalty through Satisfaction (Study on Fast Boat D'Camel Fast Ferry). American Journal of Humanities and Social Sciences Research (AJHSSR). Volume-4, Issue-3- pp-46-53.

Ferdinand, Augusty (2005). Structural Equation Modeling. BP Undip

Ferdinand, Augusty (2014). Metode Penelitian Manajemen. BP Universitas Diponegoro. Semarang.

Ghozali, Imam. (2006). Aplikasi Analisis Multivariate dengan Program SPSS. Edisi Keempat. Semarang: Badan Penerbit Universitas Diponegoro.

Goetsch, D.L. \& Davis, S. (1994). Introduction to Total Quality: Quality, Productivity, Competitiveness. Englewood Cliffs, NJ: Prentice HallInternational, Inc. p.4.

Hardiansyah (2011). Kualitas Pelayanan Publik. Yogyakarta: Gava Media

Hasan, Ali (2008). Marketing. Yogyakarta : Media Utama.

Hurriyati, Ratih. (2010). Bauran Pemasaran dan Loyalitas Konsumen. Bandung: ALFABETHA

Irnandha, Aris (2016). Pengaruh Kualitas Layanan Terhadap Loyalitas Pelanggan Yang Dimediasi Oleh Kepuasan Pelanggan Jasa Penggiriman Jalur Darat. Jurnal Manajemen Bisnis Indonesia (JMBI). Vol5, No 6 (2016).

Kotler, P., \& Keller, K. L. (2003). Manajemen Pemasaran(edisi 13 Jilid 1 dan 2). Jakarta: Erlangga.

Lovelock, C, dan John Wirtz, (2011). Pemasaran Jasa Perspektif (edisi 7). Jakarta: Erlangga.

Parasuraman, A., Zeithaml, V. A., \& Berry, L. L. (1994). Reassessment of expectations as a comparison standard in measuring service quality: implications for further research. Journal of marketing, 58(1), 111-124.

Rahmayanty, Nina. (2010). Manajemen Pelayanan Prima. Yogyakarta: Graha Ilmu.

Rohman, Abdur, (2017). Pengaruh Kualitas Pelayanan Terhadap Kepuasan Pelanggan Pada Bengkel MR. Montir Citayam. Skripsi. Jakarta. Universitas Islam Negeri Syarif Hidayatullah.

Sukerta, M., Agung, A.A.P., Sujana, I.W., (2020). Effect of Service Quality and Corporate image on Customer Loyalty with Customer Satisfaction as Mediation Variables (Study at PT. BPR. Padma, Denpasar-Bali). International Journal of Contemporary Research and Review. Volume 11, Issue 01, January, 2020.

Sugiyono (2010). Metode Penelitian Pendidikan Pendekatan Kuantitatif, kualitatif, dan R\&D. Bandung: Alfabeta

Tjiptono, Fandy. (2015). Strategi Pemasaran, Distribusi Pelanggan Pasar Branding Produk Harga (edisi keempat). Yogyakarta. Penerbit: Andi.

Tjiptono, Fandy dan Gregorius, Chandra, (2016), Service Quality dan Satisfaction (edisi keempat). Yogyakarta. Penerbit: Andi.

Zahara, Rita (2020). Pengaruh Kualitas Layanan Terhadap Loyalitas Pelanggan Dengan Kepuasan Pelanggan Sebagai Variabel Intervening. Published by LPMP Imperium. https://ejournal.imperiuminstitute.org/index.php/JMSAB

Zeitahml, VA. (1998). Consumer Perception of Price, Quality and Service, A Means Model and Syntesis of Exidence. Journal of Marketing.Vol 52. July. P. 2-22. 